
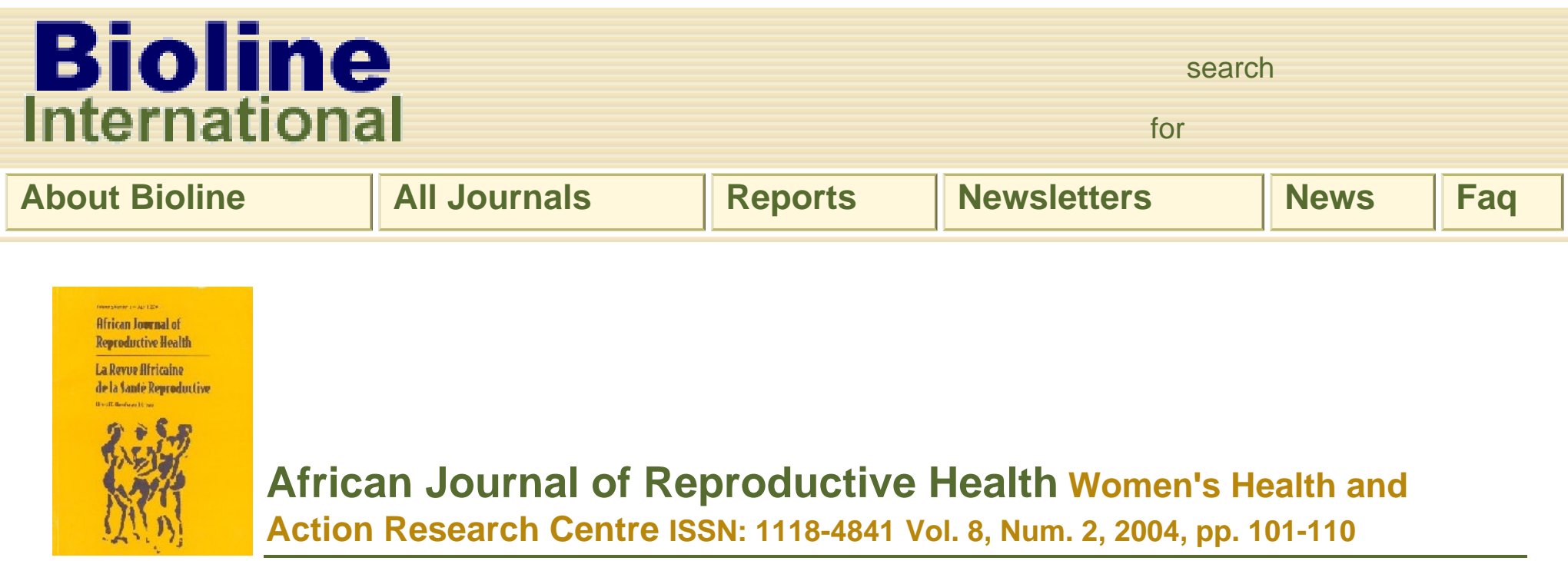

African Journal of Reproductive Health Women's Health and Action Research Centre ISSN: 1118-4841 Vol. 8, Num. 2, 2004, pp. 101-110

African Journal of Reproductive Health, Vol. 8, No. 2, Aug, 2004 pp. 101-110

\title{
Journalists' Knowledge of AIDS and Attitude to Persons Living with HIV in Ibadan, Nigeria
}

Modupeoluwa Doris Isibor ${ }^{1}$ and Ademola J Ajuwon ${ }^{1}$

${ }^{1}$ African Regional Health Education Centre, Department of Health Promotion and Education, College of Medicine, University of Ibadan, Nigeria.

Correspondence: Dr Ademola J. Ajuwon, African Regional Health Education Centre, Department of Health Promotion and Education, College of Medicine, University of Ibadan, Nigeria.E-mail: ajajuwon@yahoo.com

\section{Code Number: rh04032}

\section{Abstract}

This study surveyed 254 journalists from the seven media organisations in Ibadan, Nigeria, to assess their knowledge of acquired immune deficiency syndrome (AIDS), attitude to persons living with HIV/AIDS (PLWA) and reports of AIDS-related issues. The journalists' overall mean AIDS knowledge score was 10.6 out of 14 points. About one third (29\%) believed that the bite of a mosquito could transmit HIV and $28 \%$ thought that AIDS could be cured if detected early. Although $75.2 \%$ agreed that the rights of PLWAs to employment should be protected, $49.6 \%$ believed AIDS patients should be detained in hospital to prevent the spread of HIV. About a quarter (25.2\%) had received training about HIV/AIDS, while $74.8 \%$ had not. The majority $(65.4 \%)$ had never written any report on HIV/AIDS-related issues, while $35.6 \%$ had done so. Journalists in Ibadan do not have adequate knowledge of AIDS, and many of them show negative attitude to PLWAs, thus undermining their potential ability to educate the public about AIDS. Advocacy and training workshops are recommended to address this problem. (Afr $J$ Reprod Health 2004; 8[2]: 101-110) 
Key Words: HIV/AIDS, journalists, knowledge, attitudes, prevention

\section{Résumé}

La connaissance chez les journalistes par rapport au SIDA et leur attitude envers les personnes qui vivent avec le VIH à Ibadan, Nigéria. Cette étude a enquêté 254 journalistes tirés de sept organisations médiatiques à Ibadan, Nigéria afin d'évaluer leur connaissance du syndrome d'immunodéficience acquise (SIDA), leur attitude envers les personnes vivant avec le virus le l'immunodéficience humaine $(\mathrm{VIH})$ et les reportages des problèmes liés au SIDA. L'indice moyen de la connaissance chez les journalistes sur le SIDA était 10.6 sur 14 points. A peu près un tiers (29\%) ont cru que la piqure de la moustique peut transmettre le $\mathrm{VIH}$ et $28 \%$ ont cru que le SIDA pouvait être guéri si l'on le détecte tôt. Bien que $75,2 \%$ soient d'accord qu'il faut protéger les droits de ceux qui vivent avec le SIDA à l'emploi, 49,6\% ont cru qu'il faut retenir les malades atteints par le SIDA dans l'hôpital pour éviter la propagation du VIH. Environ un quart $(25,2 \%)$ ont suivi des cours sur le VIH/SIDA alors que $74,8 \%$ ne l'ont pas suivi. La majorité $(65,4 \%)$ n'avaient jamais écrit un reportage sur des problèmes liés au VIH/SIDA alors que $35,6 \%$ l'avaient fait. Les journalistes à lbadan n'ont pas de connaissance adéquate sur le SIDA et beaucoup d'entre eux ont des attitudes négatives envers les personnes vivant avec le SIDA, ce qui sape leur capacité potentielle pour renseigner le public sur le SIDA. Nous préconisons les ateliers de formation et de plaidoirie comme moyens de résoudre les problèmes. (Rev Afr Santé Reprod 2004; 8[2]: 101-110)

\section{Introduction}

HIV/AIDS is a global problem. In Nigeria, HIV/AIDS continues to grow despite efforts to control it. HIV prevalence among antenatal clinic attendees rose from $1.8 \%$ in 1991 to $5.8 \%$ in $2001 .{ }^{1-3}$ According to the Joint United Nations Program on AIDS, in 2001 alone AIDS killed an estimated 170,000 persons in Nigeria and about one million children were orphaned by the disease. About $5.8 \%$ of adults or 3.5 million Nigerians currently live with HIV. ${ }^{3}$ One of the factors contributing to the rapid spread of HIV in the country is widespread denial. Many citizens deny that AIDS exists in the country because they have not seen anyone infected with the disease, others perceive the dangers posed by AIDS with fatalism, arguing that a person who is not killed by AIDS will eventually "die of something else". 4 Secondly, due to the continuing economic hardship in Nigeria sex work continues to flourish in urban 5,6 and rural areas. ${ }^{7}$ Findings from one recent study suggest that actual use of condoms may be lower than that reported by female sex workers. Eremonsele 5 found that many female sex workers in two towns in south-western Nigeria have unprotected sex with special customers (boyfriends) and other clients willing to pay extra money.

Although highly active antiretroviral therapy is now widely available in many developed countries and in some developing nations including Brazil and India ${ }^{8}$, these drugs are not readily accessible to the majority of Nigerians who need them due to logistic constraints and exorbitant cost. ${ }^{9}$ Primary prevention through targeted educational interventions is one of the most realistic strategies for controlling further spread of HIV in Nigeria. The mass media including radio, 
television and newspapers have important roles to play in HIV prevention and control activities. ${ }^{10}$ The media is an efficient and less expensive method of informing and influencing people. By providing the latest research findings, the media can reduce the myths surrounding the disease. Popular entertainment such as dance, drama and music on television and radio can be creatively used to educate a large group of persons with important HIV prevention messages. In Uganda, for example, safer sex messages reached $92 \%$ of its intended audience through the media. ${ }^{11}$ Media messages delivered by popular role models can also help people change risky sexual behaviours. ${ }^{10}$ In Zambia, adolescents exposed to television campaign that promoted abstinence and condom use were $87 \%$ more likely to use condom and $47 \%$ more likely than those not exposed to abstain from sex. ${ }^{12}$ Apart from informing the public, the media can set the agenda for public discussion and influence public policy on AIDS. ${ }^{13}$

It is feasible for the mass media in Nigeria to perform these roles because most homes have access to at least one media. For example, one estimate shows that $62 \%$ of rural and $85 \%$ of urban households have radio receivers, ${ }^{14}$ and majority of people living in rural medically underserved communities depend on the radio as their main source of health information. ${ }^{15}$ Although their impact on risky behaviour has not been assessed, the Nigerian media have played an important role in raising public awareness about AIDS. Two recent surveys of young girls in vocational training and male commercial drivers show that the proportion of those who heard of AIDS on radio ranged from $88 \% 16$ to $96 \% .{ }^{17}$

Despite their potential role in HIV/AIDS prevention, some concerns have been raised about the appropriateness of media reports on AIDS in Nigeria. Nigerian journalists tend to place more emphasis on HIV/AIDS figures and little attention to their potential role in educating the public about how to prevent infection. This strategy may create fear and anxiety and may, therefore, be ineffective. Another concern is the tacit support the media gave to the Nigerian surgeon who claimed to have found a cure for AIDS 18 but would not subject his medication to scientific scrutiny. This may create the myth that a cure is now available for AIDS, thus perpetuating risky practices. These concerns have raised questions about how much knowledge Nigerian journalists have on HIV/AIDS, their attitude to PLWA and their level of preparation to perform their potential roles as public educators on HIV/AIDS. ${ }^{19}$ Few studies have attempted to provide answers to some of these questions. Jimoh had earlier analysed the contents of reports on reproductive health issues published in four newspapers in Nigeria. ${ }^{19}$ The present study specifically assessed knowledge about AIDS, attitude to PLWA and reports on AIDS-related issues by journalists in television, radio and newspapers.

\section{Methods}

The setting for the study is Ibadan, Oyo State, Nigeria. Ibadan has a population of about three million people. It is a major regional centre for trade, commerce and education in south-western Nigeria. Like most states in Nigeria, HIV exists in Oyo and continues to spread rapidly. Sentinel surveillance among antenatal clinic attendees shows that HIV prevalence rose from $3.1 \%$ in 1991 to $4.1 \%$ in $2001.1,2$ 
There were seven media organisations in Ibadan in 2002 when the survey was conducted. A profile of the organisations and their ownership status are shown in Table 1. The Federal Government of Nigeria controls one of the two radio stations and a TV channel, while one of the radio and TV stations are under the control of the state government. Individuals own one TV station and the two newspaper media. The TV channels provide daily broadcasts of programmes in English and Yoruba for approximately eight hours, from 4.00 p.m. to 12 midnight. Coverage of the TV programmes spans the six states of south-western Nigeria.

By contrast, the radio stations have wider coverage with clear receptions in all the states of the federation. However, radio broadcast targets mainly the local population, hence, the bulk of the programmes are in Yoruba, the language widely spoken in Ibadan. Radio stations also broadcast for longer periods (12 hours), beginning from 5.00 a.m. to 12 midnight, but are subject to control by the government. The newspapers are published daily in English with correspondents in different parts of the country. One of the newspapers is the oldest private news organisation in the country, having being in circulation since 1949. This newspaper has a reputable history of political activism in defence of human rights in Nigeria. Although these newspapers claim to have national coverage, their readership is mainly limited to south-western Nigeria. Consequently, their coverage of news is limited to the events in this area.

\section{Study Population}

The study population included all persons involved in news gathering, writing, editing and presentation and are affiliated to the seven media organisations in Ibadan. This includes reporters, feature writers, editors, producers and scriptwriters.

\section{Recruitment of Study Participants}

The management staff of each media organisation were contacted to inform them of the purpose of the study and seek their approval. After approval was granted, all the practicing journalists in the seven media organisations were enumerated. In all, 295 journalists were available for the survey. Each of the 295 journalists was contacted and invited to participate in the study. Two hundred and fifty four of those contacted consented to participate, giving $86.1 \%$ response rate. Each respondent gave verbal informed consent after informing them that participation in the study was voluntary, and that data collected would be used only for research purpose and kept confidential.

\section{Data Collection}

A 54-item questionnaire was developed for data collection. The questionnaire elicited information on demography, knowledge of HIV/AIDS, attitude towards PLWA, previous training on HIV/AIDS, and previous reports on AIDS-related issues. The knowledge component of the questionnaire was developed from previously tested instruments used for surveys on knowledge and HIV-related behaviours among female apprentices and male commercial bus/taxi drivers in 
Ibadan. ${ }^{16,17}$ Knowledge of HIV/AIDS was assessed in two ways. First, respondents were requested to determine which of six statements was "True" or "False" about HIV/AIDS (Table 2). Secondly, they were asked to state the prevalence of HIV in Nigeria, identify body fluids in which HIV is found, routes of mother-to-child transmission and their perception of the risks involved in blood transfusion.

Attitude was explored by requesting respondents to "agree", "disagree" or be "undecided" to eight statements, which conveyed both positive and negative dispositions to PLWA in this environment (Table 3). Finally, the journalists were asked if they had ever received any formal training on HIV/AIDS, written any report about the disease and to mention the constraints they faced in doing so. Each consenting respondent was given a questionnaire, which was collected after being completed. A draft of the questionnaire had earlier been pilot tested for clarity and comprehension of the items among 20 randomly selected journalists in Abeokuta, another capital city in south-western Nigeria.

\section{Data Analysis}

Copies of the questionnaire were collated and the data entered into a computer and analysed with EPI-INFO software developed by the Center for Disease Control and Prevention, Atlanta, Georgia, USA. HIV/AIDS knowledge was analysed by assigning one mark to each correct answer provided by the respondents. This was used to generate a 14-point AIDS knowledge score. Mean scores were derived and compared with demographic variables including gender, type of media organisation and job status. With respect to attitude, three points was assigned to those who "agree" to a positive statement and the same score was assigned to those who "disagree" with a negative statement. This calculation resulted in the development of a 24attitudinal scale, which was compared with some demographic variables.

\section{Results}

There were more male (63.4\%) than female (36.6\%) journalists. About $35.5 \%$ of them worked for the radio, 35\% for newspaper and $29.5 \%$ for TV media. More than half $(52 \%)$ had bachelors degree or its equivalent, $26 \%$ had secondary education, while $22 \%$ had postgraduate training. Concerning job status, $34.3 \%$ were reporters, $21.3 \%$ were producers, $15.9 \%$ were editors, $15.4 \%$ presenters and $13.4 \%$ features writers. Experience in journalism ranged from one to 30 years with a mean of 7.3 years. More than half $(56 \%)$ had $1-5$ years working experience. Their ages ranged from 25 to 56 years with a mean of 32 years.

\section{Knowledge of HIV/AIDS}

Response to each of the six AIDS knowledge statements by the journalists is shown in Table 2 . Eighty two per cent of them knew that HIV is the causative organism for AIDS, $84 \%$ were aware that a healthy carrier could transmit the virus, while $29 \%$ believed that bite from a mosquito could spread HIV. 
Six per cent knew that $5.4 \%$ of adult Nigerians were living with the virus as at $1999,94.6 \%$ did not know the proportion of Nigerians infected with HIV. More than half (51.2\%) could not list any of the routes for mother-to-child transmission of HIV, 48.8\% knew at least one of such routes, namely, exchange of blood during delivery. Forty two per cent did not know of any body fluid in which HIV is found, while $57.9 \%$ mentioned at least one of such fluids. Of these, majority $(61.4 \%)$ mentioned blood, followed by semen (29.3\%), saliva $3.3 \%$, urine $(2.1 \%)$, breast milk $0.5 \%$ and sweat $3.4 \%$. Forty one per cent perceived that blood donation puts the donor at risk of HIV infection while 59\% did not think so. Respondents' overall mean knowledge score was 10.6 of 14 points. Male journalists had more superior mean score $(7.8)$ than females $(7.0)(p<0.05)$. Respondents from newspaper and TV media had better mean scores (7.8 each) than their counterparts from the radio $(7.0)(p<0.05)$ media. Similarly, sub-editors had superior mean scores than others (Table 3 ).

\section{Attitude to PLWA}

The journalists' responses to the eight attitudinal statements are presented in Table 4. It shows that $23.5 \%$ agreed that PLWA should be isolated in order to protect the uninfected members of the society while $70.9 \%$ disagreed. About half (49.6\%) agreed that patients with HIV should be detained in the hospital to prevent them from spreading the virus to others, while $42.1 \%$ disagreed. The majority (72.5\%) agreed that PLWA should not be denied their rights to employment while $20.1 \%$ disagreed. Few (6.3\%) agreed that PLWA are to be blamed for their health condition while $85.9 \%$ disagreed. Virtually all (92.1\%) agreed that journalists have important roles to play in reducing the stigmatisation of HIV in Nigeria. On the whole, the journalists had a mean score of 10.06 out of 24 points. No significant difference was found when mean scores on attitude was compared with gender and type of organisation. However, presenters had more positive attitude to PLWA than others (Table 5).

\section{AIDS-Related Reports and Training}

Majority of the journalists (65.4\%) said they had never written a report on AIDS-related issue while $35.6 \%$ had done so. Many $(66 \%)$ of those who had written a report on AIDS did so in the six months preceding the survey, $34 \%$ had written such report earlier. Of the 90 persons who had written a report, the majority (61.5\%) did because of their personal interest, $24.2 \%$ were assigned to cover a government-sponsored programme, while $14.3 \%$ said their report focused on research findings provided by scientists. The main constraints journalists faced in attempting to report HIV/AIDS issues were lack of adequate educational materials (journals and books), unwillingness of PLWA to be interviewed, and perceived inadequate support from health workers. Most (88.2\%) of those who had reported about AIDS had never interviewed a PLWA to learn about their perspective while $21.8 \%$ had done so.

About one quarter (25.2\%) had been trained on HIV/AIDS and $74.8 \%$ had not. Previous training was positively related to report of AIDS. More AIDS programme participants (54.7\%) had reported AIDS issues than non-participants (43.3\%) $(p<0.05)$. However, almost all $(93.3 \%)$ were willing to participate in a training programme that would enhance their capacity to perform their roles as public educators for HIV/AIDS prevention in the country. Suggested contents for 
such training include cause of AIDS, mode of transmission of HIV, prevention, management, and strategies for helping PLWA deal with stigma associated with this condition.

\section{Discussion}

The mass media have a pivotal role to play in the fight against HIV/AIDS. ${ }^{20}$ The media can make the fight against AIDS a high priority by committing adequate time and space for HIV/ AIDS issues, providing current and accurate news coverage of the epidemic, supporting efforts to train reporters and producers to cover the epidemic, and ensuring the integration of HIV/AIDS themes in storylines. ${ }^{20}$ Nigerian journalists have also been called upon to educate the public in order to "break the wall of silence"9 that surrounds all aspects of HIV/AIDS and push an agenda that creates openness, which will allow a better appreciation of the magnitude of the AIDS problem in Nigeria. 21

Journalists will fulfil these roles only if they have adequate knowledge of HIV/AIDS. The journalists surveyed in this study were well informed about the cause of HIV and sexual route of transmission of the virus. However, some of them had inadequate knowledge of body fluids in which HIV is found; others wrongly thought that blood donation puts the donor at risk of HIV infection. Many of them also had various misconceptions such as the belief that mosquito bite could spread the virus and that AIDS could be cured if detected early. Although these findings are discouraging, they are not entirely new because similar results have been reported among other groups in lbadan including young girls in vocational training, ${ }^{16}$ and female hawkers in bus and truck stations. ${ }^{22}$ In a review of AIDS-related reports in newspapers in nine African countries, including Nigeria, Lear concluded that the newspapers surveyed were not being used as primary media of education because of several misconceptions held by journalists including the belief that AIDS is a disease affecting white people. ${ }^{23}$ The misconceptions held by journalists surveyed in this study raise concerns about their ability to perform these roles.

Journalists in this study appeared to have an inconsistent attitude towards PLWA. On one hand, about half $(50 \%)$ believed that patients with HIV should be detained in the hospital to prevent the spread of the virus. On the other hand, majority (73\%) agreed that the rights of PLWA should be protected. Of greater concern is the relatively large number of subjects who showed negative attitude to PLWA. Stigma and discrimination against PLWA is widespread in Nigeria as it is in many African countries, even where HIV is widespread. ${ }^{24}$ In a survey of Nigerian surgeons, Adebamwo and colleagues 25 found that $58 \%$ would not operate on a PLWA. Physicians and nurses hold similar attitude. ${ }^{26}$ Some churches now require mandatory testing for all couples wishing to get married and demand medical certificates of proof of negative status as a condition for marriage in the church. ${ }^{21}$ Aversion to PLWA is a major challenge to HIV/AIDS prevention activities in the country. Stigma and discrimination are counter-productive to promotional activities because they make people less likely to test for HIV, seek care and disclose their HIV status to their partners or family members. ${ }^{27}$ In some extreme cases it may make HIV positive persons to knowingly spread the virus to others.

Majority of the journalists surveyed had never received any formal training on HIV/AIDS. This 
suggests that the AIDS education needs of journalists have largely been neglected. It may also be part of the explanation of the misconception found in this population. However, this finding probably reflects the problems journalists often face in covering programmes. Our field experience shows that many journalists perceive their role in a programme as reporters of event and not as trainees per se. As a consequence, they attend only the ceremonial component of a programme and, therefore, do not learn from such programme.

Such behaviour must however be understood in the context of the difficult environment in which many Nigerian journalists operate. Shortage of staff, transportation and materials such as camera, films are chronic problems affecting many media organisations in developing countries including Nigeria. ${ }^{14}$ As a result, journalists are typically assigned to cover two to three events the same day. In some extreme cases television news reporters may have to wait for a camera to return from an assignment before they can go on another one. ${ }^{14}$ This situation places journalists under great pressure in writing their reports to meet production deadlines. The implication is that it leaves journalists with limited time to fully attend and meaningfully learn from any one programme. It may also adversely affect the quality of the report that journalists write. Finally, there is a general reluctance by the management of media organisations to fund continuing education programme for journalists on current public health issue such as HIV/AIDS since their main focus is to make profit. ${ }^{19}$

\section{Programme Implications}

The study has provided baseline data for planning appropriate intervention programmes for journalists in Ibadan. We recommend three intervention activities to address the needs identified in this survey. First, intervention must begin with the management staff of all the organisations in lbadan. We recommend an advocacy meeting for this group because as gatekeepers, the publishers, managers and directors of media organisations facilitate access to journalists and their approval and support will be crucial to the success of any intervention directed at journalists. This intervention will sensitise the management on the important roles that the media can play in HIV prevention activities.

Secondly, initial and continuing education through workshops need to be organised for all the journalists. This intervention is recommended because it has worked with secondary school students ${ }^{28}$ and health workers ${ }^{29}$ who held misconceptions on HIV/AIDS and prejudiced attitude to PLWA. Journalists could also be encouraged during the workshop to develop innovative ideas for integrating HIV/AIDS issues into their programmes. These interventions should be organised by officers of the Oyo State Ministry of Health in which journalists participate as trainees and not mere reporters of the event. The programme is likely to be well received by journalists as many have expressed a willingness to be involved.

Finally, the state Ministry of Health and other relevant agencies would also need to provide journalists with current information materials on HIV/AIDS since this is a major constraint to reporting AIDS-related issues. It would also enable them to report accurate and up-to-date information to the public. This would require creating a partnership between journalists, officers of the Ministry of Health and scientists working on biomedical and behavioural aspects of HIV/ 
Bioline International Official Site (site up-dated regularly)

AIDS. Experience from Kenya shows that such partnership is feasible and effective, as it enlists the support and cooperation of journalists in prevention programming. ${ }^{13}$ Through the partnership, journalists would have access to the latest scientific information about HIV/AIDS, which are typically published in learned journals that are usually not accessible to journalists.

\section{Conclusion}

AIDS is a growing public health problem in Nigeria. The mass media can potentially play important roles in educating the public on how to prevent infection since most homes have access to one medium of mass communication. Journalists in Ibadan currently do not have sufficient knowledge of AIDS and many harbour negative disposition to PLWA, which may undermine their ability to reach full potential as educators of HIV prevention. If properly trained and mobilised, journalists will make significant contributions to HIV/AIDS prevention activities in Oyo state, Nigeria.

\section{Acknowledgements}

We thank the management staff of the seven media organisations in Ibadan for providing the approval to conduct this survey and all the journalists who completed the questionnaire. We appreciate the helpful comments of the reviewers and those of Dr Clement Adebamwo and Mr. Bavon Mupenda on an earlier draft of this paper. We wish to thank Mr. Dele Oladoja for his efforts in data analysis.

\section{References}

1. Federal Ministry of Health and Social Services. Sentinel seroprevalence report for 1994. Lagos, 1995.

2. Federal Ministry of Health. Technical report on STD and PTS patients, Abuja, Nigeria.

3. Joint United Nations Program on AIDS. Epidemiological Fact Sheet Updates on Nigeria. December 2-7.

4. Isiuogo-Abanihe U. Extramarital relations and perceptions of HIV/AIDS in Nigeria. Health Trans Rev 1994; 117-125.

5. Eremonsele SA. Perceived susceptibility to HIV/AIDS and pattern of condom use among female sex workers in two cities in Osun state, Nigeria. MPH dissertation of the University of Ibadan, Nigeria, 2003.

6. Umar US, Adekunle AO and Bakare RA. Pattern of use of condom among commercial sex workers in Ibadan, Nigeria. Afr J Med Med Sci 2001; 30: 285-290.

7. Ajuwon AJ, Oladepo O, Adeniyi JD and Brieger WR. Sexual practices that may favor transmission of HIV in a rural community in Nigeria. Int Quart Comm Health Edu 1994; 16: 403-416.

8. McFarland W, Lindan CP, Mandel J and Rutherford G. HIV prevention in developing countries: training researchers for the long haul. AIDS and Behavior 2002; 6(3): 207- 
209.

9. Alubo O. Breaking the wall of silence: AIDS policy and politics in Nigeria. Int $J$ Health Serv 2002; 32(3): 551-556.

10. Family Health International. Mass Media and HIV/AIDS Prevention. Arlington, Virginia, USA.

11. Lewicka N, Kiragu K and Young S. Delivering of improved services for health project in Uganda: Evaluation of safe sex for AIDS communication campaign. Johns Hopkins University Center for Communication Programs, 1998, p51.

12. Underwood C. Impact of the heart campaign: from the youth surveys in Zambia. Johns Hopkins University Center for Communication Programs, 2001, 24-30.

13. Tuju R, Origombe M and Henry K. HIV/AIDS prevention through the mass media. Family Health International, Arlington, Virginia, case study 10, 149-157.

14. Giluly RH and Moore SH. Radio-spreading the word. Pop Reports 1986; 14: J853-856.

15. Brieger WR. Mass media and health communication in rural Nigeria. Health Pol Plann 1991; 5(1): 77-81.

16. Ajuwon AJ, McFarland W, Hudes ES, Adedapo SA, Okikiolu T and Lurie P. HIV riskrelated behavior, sexual coercion and implications for prevention strategies among female apprentices tailors, Ibadan, Nigeria. AIDS and Behavior 2002; 6(3): 229-235.

17. Akintola O. Knowledge about AIDS and risky sexual behavior of commercial drivers in Ibadan. MPH dissertation of the University of Ibadan, Nigeria, 2000.

18. AIDS infects 0.8 million Lagosians. The Punch. 3rd May 2001, p5.

19. Jimoh A. Developing mass media communication strategies for improving reproductive health promotion in Nigeria. Unpublished report, 1999.

20. United Nations Programme on AIDS. Global Media AIDS Initiative. What Media Can Do. Geneva: United Nations.

21. Hargreaves S. Time to right the 2003wrongs: improving basic health care in Nigeria. The Lancet 2002; 359(9322): 2030-2035.

22. Ajuwon AJ, Fawole Ol and Osungbade KO. Knowledge of AIDS and sexual practices of young female hawkers in truck and bus stations in Ibadan, Nigeria. Int Quart Comm Health Edu 2001; 20(2): 133-143.

23. Lear D. AIDS in the African Press. In: Buchanan D and Cernada G (Eds.). Progress in Preventing AIDS: Dogma, Dissent and Innovation. New York: Baywood Publishing Company, p215-226.

24. Brown L, Macintyre $\mathrm{K}$ and Tujillo L. Interventions to reduce HIV/AIDS stigma: What have we learned? AIDS Edu Prev 2003; 15(1): 49-69.

25. Adebamowo CA, Ezeome ER, Ajuwon AJ and Ogundiran TO. Survey of the knowledge, attitude and practice of Nigerian surgery trainees to HIV-infected persons and AIDS patients. Biomed Central J 2002; 147.

26. Nasiru A, Olaseha IO, Adeniyi JD and Ajuwon AJ. Knowledge and attitude of physicians and nurses about AIDS in Sokoto, Nigeria. Int J Health Edu 1998; 36(1): 26-28. 
27. United Nations Children Fund. Young People and HIV/AIDS: Opportunity in Crisis. New York: UNICEF, 2002.

28. Fawole IO, Asuzu MC, Oduntan SO and Brieger WR. A school-based AIDS education programme for secondary school students in Nigeria. A review of effectiveness. Health Edu Res 1999; 14(5): 675-683.

29. Ezedinachi EN, Ross MW, Meremiku M, Essien EJ, Edem CB, Ekure E and Ita O. The impact of an intervention to change health care workers' HIV/AIDS attitudes and knowledge in Nigeria: a controlled trial. Public Health 2002; 116: 106-112.

CWomen's Health and Action Research Centre 2004

The following images related to this document are available:

Photo images

[rh04032t5.jpg] [rh04032t2.jpg] [rh04032t4.jpg] [rh04032t3.jpg] [rh04032t1.jpg]

\begin{tabular}{|l|l|l|l|}
\hline Home & Resources & Mailing List & Email Bioline \\
\hline
\end{tabular}

(c) Bioline International, 1989 - 2004, Site last up-dated on 20-Jan-2005. 
Table 5 Mean Scores for Attitudes towards Persons Living with HIV/AIDS among Journalists in Ibadan, Nigeria $(\mathrm{N}=254)$

\begin{tabular}{|c|c|c|c|c|}
\hline Item & No. & Mean Score* & SD & P value \\
\hline \multicolumn{5}{|l|}{ Gender } \\
\hline Male & $1 / 1$ & $\Omega \Omega 4$ & 2.15 & $0.7 / 60$ \\
\hline Female & 93 & 10.09 & 3.27 & \\
\hline \multicolumn{5}{|l|}{ Type of media } \\
\hline Rajio & 90 & 10.23 & 2.84 & \\
\hline TV & 75 & 9.96 & 3.31 & 0.857 \\
\hline Newspaper & 89 & 9.97 & 3.43 & \\
\hline \multicolumn{5}{|l|}{ Job status } \\
\hline Reporter & 87 & 9.44 & 3.37 & \\
\hline Sub-editor & 20 & 10.05 & 3.54 & \\
\hline Assistant editor & 20 & 8.85 & 2.66 & 0.037 \\
\hline Producer & 54 & 10.72 & 3.00 & \\
\hline Presenters & 27 & 10.77 & 2.79 & \\
\hline Others & 43 & 10.74 & 1.99 & \\
\hline
\end{tabular}




\section{Table 2 Knowledge of HIV/AIDS among Journalists in Ibadan, Nigeria}

An infected person can spread HIV without showing clinical signs 
Table 4 Journalists' Responses of to HIV-Related Statements

Statement

People living with HIV should

be isolated

Patients with HIV should be

detained in hospital to prevent

re-infecting others

PLWA are to be blamed for

their condition

Government should provide

free drugs for people

living with HIV

People living with HIV

should not be denied employment

Subsidising drugs for AIDS

treatment is a waste of national resources

Journalists have important roles to play

in reducing stigma associated with HIV

AIDS patients should be promptly

discharged from hospital to prevent

spread to other patients

\section{Agree (\%) $\quad$ Disagree (\%) $\quad$ Undecided (\%) $\quad$ Total (\%)}

$60(23.5) \quad 180(71) \quad 14(5.5) \quad 254(100)$

$126(49.6) \quad 107(42.1) \quad 21(8.3) \quad 254(100)$

$16(6.3) \quad 218(85.9) \quad 20(7.8) \quad 254(100)$

$209(82.3)$

$17(6.7)$

$28(11) \quad 254(100)$

$179(70.5)$

$51(20.1)$

$24(9.4) \quad 254(100)$

$18(7.1)$

$222(87.4)$

$14(5.5)$

$254(100)$

$236(92.9)$

$6(2.3)$

$12(4.8)$

$254(100)$

$6(3.9)$

$236(92.9)$

$12(4.7)$

254 (100) 


\section{Table 3 Mean HIV/AIDS Knowledge Scores among Journalists in Ibadan, Nigeria $(\mathrm{N}=254)$}

\begin{tabular}{lrccc}
\hline Item & No & Mean score* & SD & P value \\
\hline Gender & & & & \\
$\quad$ Male & 161 & 7.8 & 3.17 & 0.038 \\
$\quad$ Female & 93 & 7.0 & 3.04 & \\
Tjpe of media & & & & \\
$\quad$ Radio & 90 & 7.0 & 2.46 & \\
TV & 75 & 7.8 & 3.22 & 0.001 \\
Newspaper & 89 & 7.8 & 3.62 & \\
lob status & & & & \\
Reporter & 87 & 7.7 & 3.58 & \\
Sub-editor & 20 & 8.2 & 2.90 & \\
Assistant editor & 20 & 7.0 & 2.88 & 0.042 \\
Producer & 54 & 6.7 & 2.41 & \\
Presenters & 27 & 7.0 & 2.76 & \\
Others & 43 & 8.4 & 3.14 & \\
\hline
\end{tabular}




\section{Table 1 Profile of Media Organisations in Ibadan, Nigeria}

\begin{tabular}{lcccccc}
\hline Media type & \multicolumn{2}{c}{ Government-owned } & \multicolumn{2}{c}{ Private } & \multicolumn{2}{c}{ Total } \\
& $\begin{array}{c}\text { No. of } \\
\text { organisations }\end{array}$ & $\begin{array}{c}\text { No. } \\
\text { interviewed }\end{array}$ & $\begin{array}{c}\text { No. of } \\
\text { organisations }\end{array}$ & $\begin{array}{c}\text { No. } \\
\text { interviewed }\end{array}$ & $\begin{array}{c}\text { No. of } \\
\text { organisations }\end{array}$ & $\begin{array}{c}\text { No } \\
\text { interviewed }\end{array}$ \\
\hline Television & 2 & 56 & 1 & 19 & 3 & $75(29.5 \%)$ \\
Radio & 2 & 90 & 0 & 0 & 2 & $90(35.5 \%)$ \\
Newspaper & 0 & 0 & 2 & 89 & 2 & $89(35 \%)$ \\
\hline Total & 4 & 146 & 3 & 108 & 7 & $254(100 \%)$ \\
\hline
\end{tabular}

